\title{
PERSON'S LIFE CHANGING AFTER TRAUMA: A NARRATIVE ANALYSIS
}

\section{Tytarenko T. M.}

\section{INTRODUCTION}

The influence of traumatic experience to personal transformations is poorly understood until now. Studying the changes in an individual's life caused by engaging in combats is usually concentrated around post-traumatic stress disorders [Belrose, $\mathrm{C}^{1}$; Crone D.M. ${ }^{2}$, Waysman, M. ${ }^{3}$ ].The discourse on the psychosocial reintegration of combat veterans returning from Iraq and Afghanistan indicates that the current medical model is insufficient. The same processes that cause veterans to split off their experiences also cause society as a whole to distance itself from them [M. Bragin $\left.{ }^{4}\right]$.

According to French scientists, the successful reintegration of soldiers is associated with the resumption of communication with the help of their own personal resources: the level of mindfulness, optimism, self-esteem, wisdom, and courage that provide constructive changes in later life ${ }^{5}$. Some authors discuss this relationship between politics, wider societal practices, and posttraumatic stress ${ }^{6}$.

The psychological aspects of a person's lifechanging after trauma, the ways of comprehending a traumatic experience, and renewed life prospects remain on the periphery of the scientist's attention. So, this study has in focus

\footnotetext{
${ }^{1}$ Belrose C., Duffaud A.M., Dutheil F., Trichereau J., \&Trousselard M. Challenges Associated with the Civilian Reintegration of Soldiers with Chronic PTSD: A New Approach Integrating Psychological Resources and Values in Action Reappropriation. Frontiers in psychiatry. 2019. Vol. 9, № 737. P. 50-60.

${ }^{2}$ Crone D.M., Sarkar M.,Curran T., Baker C., Hill D., Loughren E., Dickson T., \&Parker A. Mental Health first aid for the UK Armed Forces. Health Promotion International. 2019. DOI: 10.1093/heapro/day112

${ }^{3}$ Waysman M., Schwarzwald J. \& Solomon Z. Hardiness: An examination of its relationship with positive and negative long-term changes following trauma. J. Traum. Stress. 2005. Vol. 14. P. 531-548. - doi:10.1023/A:1011112723704

${ }^{4}$ Bragin M. Can anyone here know who I am? Co-constructing meaningful narratives with combat veterans. Clinical Social Work Journal. 2010. Vol.38, № 3. P. 316-326.

${ }^{5}$ Belrose C., Duffaud A.M., Dutheil F., Trichereau J., \&Trousselard M. Challenges Associated with the Civilian Reintegration of Soldiers with Chronic PTSD: A New Approach Integrating Psychological Resources and Values in Action Reappropriation. Frontiers in psychiatry. 2019. Vol. 9, № 737. P. 50-60.

${ }^{6}$ Muldoon O. \& Lowe R. Social Identity, Groups, and Post-Traumatic Stress Disorder. Political Psychology, 2012. Vol. 33. № 2. P. 259-273.
} 
on life after combatants returning from the war in the East of Ukraine. They were asked about stressful events, rethinking of traumatic experience, new perspectives that a person builds upon returning from the war zone.

Therefore, the purpose of the work is to identify common types of person's life landscape transformations after participation in the war. To address this challenge, it will be analyzed the topics of trauma that the respondents considered to be the most serious. Second, the ways of changing war-affected life will be spoken about. It will be determined the nature of the changes that occur and are planned in their lives after returning from the war. And, third, it would be determined the most common types of life-landscapes.

\section{The topics of post-traumatic combatant narratives}

The narrative research methodology is ever-maturing evolving, and researchers must understand the benefits and institutional barriers of such a qualitative approach. Participants often live with serious illness (cancer, endstage renal disease, HIV/AIDS). Qualitative researchers engaged in narrative research propose both thematic analysis and a case centered approach for emphasizing individual agency, particularities, and context ${ }^{7}$.

There is a growing number of works that use narrative analysis recently, in work with the participants of the combats. D. Carless ${ }^{8}$, for example, uses a dialogical narrative approach to analyze the effects of personal changes on participants in a rehabilitation training course for traumatized soldiers. The goal of the interpersonal process of treatment can then be facilitated through the co-creation of a consistent narrative, shared by both therapist and patient, that binds past to present $[\mathrm{M} \text {. Bragin }]^{9}$. In his work to support veterans in Liberia, J. Mcmullin analyzes two narratives: the threat of peace by combatants and the outrage from a community that finds its members more deserving of help than veterans ${ }^{10}$. P. Arthur ${ }^{11}$ studies how traditional physical

\footnotetext{
${ }^{7}$ Bruce A., Beuthin R., Shields L., Molzahn A., \& Schick-Makaroff K. Narrative Research Evolving: Evolving Through Narrative Research. International Journal of Qualitative Methods. 2016. Vol. 15, № 1. URL: https://doi.org/10.1177/1609406916659292

${ }^{8}$ Carless D. Narrative Transformation Among Military Personnel on an Adventurous Training and Sport Course. Qualitative health research. 2014. Vol. 24, № 10. P. 1440-1450. URL: https://doi.org/10.1177\%2F1049732314548596

${ }^{9}$ Bragin M. Can anyone here know who I am? Co-constructing meaningful narratives with combat veterans. Clinical Social Work Journal. 2010. Vol.38, № 3. P. 316-326.

${ }^{10}$ Mcmullin J. Integration or separation? The stigmatisation of excombatants after war. Review of International Studies. 2013. Vol. 39., № 2. P. 385-414. DOI:10.1017/ S0260210512000228Muldoon O. \& Lowe R. Social Identity, Groups, and Post-Traumatic Stress Disorder. Political Psychology, 2012. Vol. 33. № 2. P. 259-273.

${ }^{11}$ Arthur P. Trauma Online: Public Exposure of Personal Grief and Suffering. Traumatology. 2009. Vol. 15, № 4. P. 65-75.
} 
memories of war differ from online memories, using the personal stories told by individuals who returned. Narrative interviews were used by L. Jones, and $\mathrm{K}$. Kafetsios when studying adolescent mental health in war-affected Bosnian society. They were offered to the representatives of two communities on opposite sides of the conflict to write stories entitled "What War Means to Me and How It Has Affected My Life" ${ }^{\prime 2}$.

In accordance with the task of the traumatic experience themes analyzingand further examining changes in life after trauma, it was used the written narrative method. The selected narrative method has in addition to the diagnostic potential the rehabilitative one. After all, as it known, the story about their experience significantly helps people to integrate negative experiences, to accept painful traumatic experiences, to rethink their role in what has happened, to see new horizons of life.

The combatants were asked to write stories entitled "How is my life after traumatic events". The study participants were asked to write stories based on the proposed post-traumatic narrative scheme. The scheme included the following points:

1. Which of your experiences was most traumatic for you?

2. How has your life changed after experiencing traumatic events?

3. How did you overcome the negative effects of the traumatic experience?

4. Whose support did most help you to return to a peaceful life (family, friends, etc.)?

5. How did the traumatic experience affect your vision of the future?

The sample consisted of the 91-combatant returning from the front. Most of them are servicemen who are now students of one of the military higher educational establishments in Kyiv. In addition to the military, volunteers who returned from the war and underwent psychological rehabilitation participated in the work. This sample was chosen because the extreme war conditions are known to stimulate a person to rethink the experience gained, to find new semantic priorities, to try out other practices, to consider other life prospects.

The first stage of analysis was descriptiveanalysis. The texts were read and re-read several times in order to determine the structure and content of lifestories written by combatants ${ }^{13}$. All fragments of the interviews were coded

\footnotetext{
${ }^{12}$ Jones L., \&Kafetsios K. Assessing adolescent mental health in war-affected societies: The significance of symptoms. Child Abuse \& Neglect. 2002. Vol. 26, № 10. P. 1059-1080. URL: https://doi.org/10.1016/S0145-2134(02)00381-2

${ }^{13}$ Zięba M., Wiecheć K., Biegańska-Banaś J., \&Mieleszczenko-Kowszewicz W.Coexistence of Post-traumatic Growth and Post-traumatic Depreciation in the Aftermath of Trauma: Qualitative and Quantitative Narrative Analysis. Frontiers in Psychology. 2019. Vol. 10. DOI: 10.3389/fpsyg.2019.00687
} 
by themes: traumatic experience, life changes, negative effects, vision of the future. The second stage of analysis was the interpretative one. There were made attempts to identify personal life landscape transformations after participation in the war.

In analyzing the results, 10 of the author's texts were excluded from the general sample because their authors did not write stories about the effects of the injury. They only insisted that did not see any point in sharing their experiences with someone. Probably, all these people in one way or another have camouflaged the insufficiently interpreted and assimilated traumatic experience, displaced it from their consciousness.

As it turned out, the most traumatic war-situations were described as by far not all participants in the study. Only $41.9 \%$ of narrators referring to the most traumatic event, called the death of their comrades, their own injuries, or massive shelling by the Russian Federation, especially in 2014. They also wrote about psycho-trauma resulting from the civilians' deaths, especially children; their own decisions which sometimes threatened their subordinates' lives; the severity of the communication to the victim's families; the comrades' betrayal, especially during the Crimea annexation; the extremely painful corpse's recognition and the dead transportation.

The second most prevalent were narratives focusing on family injuries $(24,7 \%)$. This group mainly includes texts about divorce occurred while the narrator was in the combat zone or immediately upon their return home. It was also about combatant's betrayed by a loved one; the painful break of relationships that have not stood the test of separation; about loneliness after a failed marriage. Particularly dramatic stories were related to the mother's refusal to allow the children's father to see them after divorce.

The texts in which the narrator spoke about the grievous losses he had suffered before the war were in third place (23.5\%). It was a traumatic experience related to the death of a father, mother, other family members, as well as experiences about their serious illnesses, disabilities and so on.

Separately, a group of narratives dedicated to other traumas was highlighted $(9,9 \%)$. Combatants most often pointed outtraumas associated with the need to adapt to harsh conditions at a new duty station. They also wrote about unexpected transfers to another location, about the difficult regime in a military university, or about the inadequate requirements of a commander.

Some narratives describe several traumatic experiences that relate to different life contexts. In this case, preference was given to the most thoroughly characterized trauma and its consequences for the subsequent life of the individual. 
Extreme conditions stimulate a person not only to rethink the experience gained but also to search for new life-priorities, the approbation of other activities, consideration of other life prospects. Therefore, the next stage of the investigation was related to the analysis of life after trauma, present, which is being built, and the future, which is being planned.

\section{Ways to change war-affected lives}

There were the following four points to focus on setting the task of exploring changes in a person's life after experiencing trauma.

1. It has analyzed the comprehension of a person's own past, determine the degree of traumatic experience

2. It was taken into account the assessment of his / her present, which consisted of some life contexts, to which the author had referred.

3. It was studied how a person sees her/his future, which was determined by analyzing their intended life prospects.

4. In interpreting narratives, it was highlighted the most important value that dominates a person's life upon returning from the front.

According to these criteria, it was possible to see an integral indicator of personal transformations, namely the value-meaning configuration of life.

Let's start with the past, that is, to understand the traumatic experience presented in narratives. It was taken into account three levels of its comprehension and assimilation: low, medium and high.

The lowlevel manifests in the absence of pronounced temporal dynamics within the narrative, the author's immersion solely in painful situations from the past without any attempt to see their connection with the present or the future. This level corresponds to $25.9 \%$ of the narratives of combatants.

The mediumlevel is characterized by the transition from stories of complex traumatic events to certain aspects of the present life situation. The authors of these narratives had sufficient time and internal resources to understand the traumatic experience. The traumas experienced are no longer perceived as acute. But the traumatic experience is not yet sufficiently assimilated, which hinders future plans. $13.6 \%$ of the narratives correspond to this level.

The high level implies a pronounced dynamic of the narrative's temporal structure, with logical transitions from the past not only to the present but also to the future. There are a rethinking and assimilation of the traumatic experience. Emphasis is placed on the appreciation of one's own resilience, courage, and responsibility, which have helped one to survive. All this makes it possible to build real-life plans that are already beginning to be realized. The majority of the sample corresponds to this level $-60.5 \%$.

The next step in the analysis is addressedin the present life, consisting of different life contexts, to which the author of the story draws attention. 
In terms of attitude to the present, all narratives were divided into two groups. The first group consists of texts centered around only one life context related to the past. The second group contains narratives that describe several different contexts of a person's life related to his/her present.

According to our data, in some narratives, the attitude to the present is practically absent, since the authors focus solely on their own past. It is about the only one context, most often traumatic. Namely, about the trauma conditions, the situations that led to it, the complex emotional states that a person has experienced. All other related to the present life contexts are not covered. There is one-third of such narratives $(29.3 \%)$ in the total sample.

In most narratives, the attitude to the present is described in two or three contexts of life. Most often it is about professional life, relationships with loved ones, with friends who actively helped to deal with the effects of trauma, and about personal achievements. The total number of such narratives is $70.7 \%$.

The third step of the analysis was to analyze the person's attitude toward the future. It was identified three levels of this attitude: low, medium and high. The level of attitudes towards the future will be considered low when there is no mention of life plans and perspectives in the post-traumatic narrative. The level of attitude to the future will be considered average when the future is perceived by the authors of the narratives as too abstract or idealized, detached from the concrete realities of the present. The level of attitude towards the future will be considered high when the authors of the text focus attention on life plans and perspectives. These plans are perceived quite realistically, taking into account the life circumstances and inner capabilities.

The low level of attitude to the future was attributed in $25,9 \%$ of selfnarratives. Because the authors have devoted these texts to the trauma experienced, if they talk about the future, it is mainly in the context of treatment, recovery, and assistance from the state. Other vital contexts in which the victim's own efforts would be considered are hardly discussed.

The average level of attitude to one's own future is monitored in $17.3 \%$ of texts. The authors of these narratives are characterized by a non-specific, idealized vision of life prospects. For example, they say about continuing to improve themselves, to develop.

A high level of attitude towards one's own future was recorded in more than half of the analyzed texts (56.8\%). Some authors talk about a common future with loved ones, a desire to spend as much time as possible with their wife, children, parents, about starting a new family. Others emphasize the desire to continue fighting for Ukrainian statehood. Several research participants plan to work more in NGOs and volunteer organizations. There are also those who plan to develop professionally in 
the future to improve their financial situation. No fewer specific plans are made by combatants who want to go to fitness centers more, to relax, to improve health systematically.

According to our plan, the fourth step in the analysis of narratives is the attempt to highlight the most significant value dominant around which a person's life is being built up after experiencing trauma. There were 5 such dominants in the texts: the value of life and survival, the value of relationships, the value of benefits for others, the value of self-development and the value of career. The narrative analysis made it possible to trace the 5 multi directed life-trajectories that were based on the main value dominants. It was described in more detail, given the popularity of each one.

First, let's mention the studies related to heterogeneous trajectories of life after trauma. Psychologists have studied the life trajectories of 10835 responders who survived a terrorist attack on the World Trade Center. The majority is in a resistant/resilient trajectory and the rest are exhibiting chronic, recovering or delayed-onset symptom trajectories [Pietrzak, 2014] ${ }^{14}$. As a result of Australian monitoring subsets of patients there were noted such posttraumatic life-trajectories as chronic, recovery, worsening/recovery, worsening and resilient [Bryant, 2015] ${ }^{15}$. Thus, the context of PTSD is dominant to study life-trajectories. Post-traumatic narratives were analyzed in another context - context of the most significant value dominant around which a person's life is built up after experiencing traumaprime life-value, around which a person constructshis own life.

Let's start with the value "life and survival" (25.9\%). The authors of these narratives focus on the tragic circumstances in which they find themselves, for example, writing about the painful search for the murdered friends. Now they emphasize the value of life as such, writing that they have begun to value time more, "because you never know what your future is and what may happen tomorrow".

A new life trajectory after trauma for $25,9 \%$ combatants is being oriented to the dominant value"meaningful relationships". "Now I spend much more time on everyday life because family and children are the most valuable, they need me most"; "I've been taught to keep what you have and always seek compromises with my loved one".

${ }^{14}$ Pietrzak R.H., Feder A., Singh R., Schechter C.B., Bromet E.J., Katz C.L., Southwick S. Trajectories of PTSD risk and resilience in World Trade Center responders: an 8-year prospective cohort study. Psychological Medicine. 2014. Vol. 44, № 1. P. 205-219.

${ }^{15}$ Bryant R.A., Nickerson A., Creamer M.C., O’Donnell M., Forbes D., Galatzer-Levy I.R., McFarlane A.C., \&Silove D.M. Trajectory of post-traumatic stress following traumatic injury: 6-year follow-up. The British journal of psychiatry. 2015. Vol. 206, № 5. P. 417-423. 
A new life trajectory after trauma for $17,3 \%$ combatants is being oriented to the dominant value "benefits for others". The volunteer, who lost his sight as a result of a serious injury, writes: "I realized that by helping others, I thank the people who helped me. When I helped someone, I felt needed in this world". Another study participant wrote: "Before the war, I'd thought the most important thing was making money. Now I know that the main thing is to be of benefit to society, to build our country".

A new life trajectory after trauma for $17,3 \%$ combatants is being orientedto the dominant value "self-development". Veterans write: "I used to blame my parents for everything, but now I know that I can do everything myself. I constantly learn to overcome my weaknesses and wonder at which swamp I used to sit in before; "I constantly improve, play sports, learn English, wanting to be a leader, to succeed".

The last life trajectory after trauma for $13,6 \%$ combatants is being oriented to the dominant value "career". One study participant reflected: "Well, now I have a decent profession, lots of plans and good career prospects". Another author of the post-traumatic narrative writes: "Now I am not afraid of changes and trials, so I have the advantages of moving to the capital, I have a new environment of activity, a better position".

Now, focusing on all four criteria of changes in a person's life after experiencing trauma (past, present, future, most significant value), it is talking about an integral indicator of personal transformations.

\section{Types of combatant's personal life-landscapes}

To define the typical territories of personal change, the thesaurus of psychological concepts requires the introduction of a new concept - a person's life landscape transformations. In ouropinion, this concept integrates maximally the personal change heterogeneous dynamics that is recorded in our narratives, especially the development of life after war-caused trauma.

The history of the term "landscape" as a social category is quite colorful. This term is used by cultural anthropologists, sociologists, historians, social philosophers, who testify both to the complex interdisciplinary nature of the relevant phenomenon and to the insufficient conceptualization of the concept. Developing Humboldt's opinion, G. Ermischerbelieves that it is precisely the way in which a person perceives the landscape and forms ideas about the environment that transforms the environment into a landscape. Ideas of humanism, religious beliefs, economics, technologies not only affect the landscape but also shape $\mathrm{it}^{16}$. In the works of N.V. Basov and

${ }^{16}$ Ermischer G. Mental landscape: Landscape as idea and concept.LandscapeResearth. 2004. Vol. 29, № 4. P. 371-383. 
V.V. Vasylkova ${ }^{17}$, O.V. Mishchenko ${ }^{18}$, O.O. Susskaya ${ }^{19}$, T.I. Chernyaeva $^{20}$, R. Hartley ${ }^{21}$, N. Hunt ${ }^{22}$, there are focused on such diverse types of landscapes as intellectual, sacred, media, post-conflict, the landscape of happiness, trauma landscape. Although it was not yet encountered personally oriented psychological studies of this phenomenon, the above designation of its types becomes clear proof that specific psychological component is presented in this little-studied phenomenon.

A person designs and constructs his/her life landscape in accordance with the acquired and learned experience, attitudes about his past, present and future, the most important values. Each new life landscape arises when a person is undergoing hardship. Going through crises, he/she makes new life choices, sets forecast horizons, partially changes the meaningful environment, and tests the life-trajectory. Staying within the new landscape will continue as long as the chosen direction of movement through life corresponds to the actual life tasks and values of a person.

The working definition of the life-landscape is this. The landscape is a temporary territory of personal changes that have its own value-semantic configuration. The landscape is constructed by individual following the significant life contexts. The relative structural and vector stability of a particular landscape is ensured by the level of comprehension of the acquired over a certain period of life experience, relevant personal value priorities, ways to overcome crisis situations, strategic life choices, and the horizon of prospects.

If life flows for a long time, without disappointment in oneself, in the chosen profession, without treachery, betrayal, forced necessity to change the place of residence, then a person is long-delayed within one or another landscape. But still, at a new age stage, a person will have an urgent need to review the content of his/her life, its values, and direction. Every serious

17 Василькова В.В., Басов Н.В. Интеллектуальный ландшафт: концептуализация метафоры. Журнал социологии и сочиальной антропологии. 2011. № 14 (4). С. 22-40.

18 Міщенко О.В. Сакральний ландшафт: зміст і функції. Вісник нац. ун-ту ім. Т. Шевченка. Географія. 2018. № 1 (70). С. 83-88.

19 Сусська О.О. Інституціональністьvs проспериті. Про зміни медіа-ландшафту та методологічні лакуни соціології масових комунікацій. Соціологія: теорія, методи, маркетинг. 2019. № 1. С. 56-72.

20 Черняева Т.И. Ландшафты счастья: эмоциональные основания современного потребления. Известия Саратовского университета. Серия Философия. Психология. Педагогика. № 13. С. 90-94.

${ }^{21}$ Hartley R.J. Signifying the Place of Unforgettable Memory: Atrocity and Traumaina PostConflict Landscape. Anthropology Faculty Publications.University of Nebraska-Lincoln. 2014. URL: http://digitalcommons.unl.edu/anthropologyfacpub/58

${ }^{22}$ Hunt N. Landscapes of trauma. The psychology of battlefield. London, New York : Routlege, 2020. 220 p. 
ordeal, such as war, requires a person new life-changing project. The realization of these projects involves the transformations of attitudes towards oneself, change of attitudes for others and the variations in selfactualization practice. Therefore, landscapes change when difficult, extreme situations unfold, when anindividual experiences traumatic events, when old values are no longer working and significant meanings are exhausted.

The task was to determine the types of combatants' life-landscapes after returning from the war. The following 5types of landscapes have been identified: existential, communicative, volunteering, self-realization, pragmatic.

The characteristics of the existential landscapeare the inability to rethink the traumatic past, to assess the present adequately, to construct the future. The dominant life-value is survival.

The characteristics of the communicative landscape area high level of understanding of the past, adequate assessment of the present, detailed construction of the future. The dominant life-value is meaningful relationships.

The characteristics of the volunteering landscape are thorough interpretation and assimilation of the traumatic past experience, adequate assessment of current contexts of the present, a high level of future life priorities vision. The dominant life-value is benefits for others.

The characteristics of the self-realization landscapeare quite a high level of understanding of the past, high attitude to the present, idealized vision of the future. The dominant life-value is self-development.

The characteristics of the pragmatic landscape are a medium level of understanding of the past, not a high attitude to the present mainly one lifecontext, medium level of the attitude toward the future. The dominant lifevalue is career advancement.

The most common landscapes are existential and communicative ones ( $25.0 \%$ each); landscapes of volunteering and self-realization (17.3\% each) are in second place; on the third - pragmatic one (13.6\%).

The existential landscape is typical of at least one in four respondents. This figure could have increased significantly if it will be considered the 10 self-narratives in which the military refuses to talk about the war-affected experience. They write only about their own ability to deal with all the problems on their own or demonstrating other powerful psychological protections.

According to our data, the main symptoms of deterioration of psychological health during post-traumatic personal transformations are a decrease in the tendency to cooperate, a decrease in empathy, a reluctance to build life prospects, an inability to enjoy everyday life, a sense of splitting, 
lack of integrity ${ }^{23}$.These symptoms, in their totality, can push a person into a difficult and uncomfortable existential landscape. Nevertheless, the main thing when choosing a landscape is a new value-based configuration of lifedesigning.

The existential landscape accumulates the experience of the post-traumatic stage of life as a special, awareness of the different meaningful content of the new life route. The basic functionality of the existential landscape has been found, which is to create the conditions for reflection, reinterpretation, and integration of traumatic experiences that a person acquires in a border situation, in dramatic or tragic circumstances. The existential landscape is regarded as the shortest path for the individual to recover and improve his/her psychological health. Dependence of the length of individual stay within the existential landscape on the force of trauma (peculiarities of losses, the intensity of painful memories) and the hardiness resource is revealed.

The communicative landscape is no less common than existential one for combatants. This landscape as usual occurs after a person has been in the existential landscape for some time. The communicative landscape is being built on the background of finding one's community, kinship with others, restoring trust. In some cases, this landscape emerges after a period of distancing from once significant and now almost alien people. The rigid boundaries of one's personal space are created by the fact that during the ordeal some old friends and family members began to be guided by other values. They did not understand the combatant's values, did not share his vision of the life-situation. Some of them voted for other presidential candidates or even got passports of another state.

The narrators who chose the communicative landscape began to value much more mutual support, mutual understanding with friends and loved ones. They have become more open with the people they now trust, who they sympathize with, whom they love. They were willing to show greater tolerance for colleagues, even if they were too talkative, or emotionally unbalanced. The main thing is that these people have the same socio-political orientations and moral and psychological beliefs.

The life-landscapes of volunteering and self-realization are in the next place by prevalence after existential and communicative ones.

The volunteering landscape ordinary occurs after the person had remained in the existential landscape during a certain period, which was necessary to comprehend and assimilate the acquired traumatic experience. Combatants choose this landscape when their main desire is obvious - to serve their

${ }^{23}$ Титаренко Т.М. Психологічне здоров'я особистості: засоби самодопомоги в умовах тривалої травматизації: монографія. Кропивницький : Імекс-ЛТД. 2018. 160 с. 
country, to protect it from the enemy. Only in such voluntarily chosen activities do they now find meaning for themselves, the only way they feel necessary, in demand, and understand their life as the only right one in a given circumstances.

Those combatants who are ready, after an existential rethinking of the trauma experienced, to focus on their personal growth choose the landscape of self-realization. For them, at the new stage of life, it is most important to analyze the usual ways of overcoming difficulties and to prepare for future challenges as best as possible. Therefore, they are ready to purposefully develop their abilities, learn foreign languages, find new areas of application of their strengths, train endurance, promote a healthy lifestyle.

The pragmatic life-landscape is the least common one in our combatants' narrative investigation. This landscape is chosen when a certain level of mental health recovery has already been achieved, but daily life is not satisfying because it is not perceived as a way for greater safety. In this case, active, ambitious, purposeful people aim to dive into work as much as possible, to make money, to achieve success, gain career advancement and recognition. Such a "tangible", significant result of one's own efforts, apparently, seems to be certain protection from future injuries.

Prospects for further research. It is envisaged carrying out a comparative analysis of combatant's life-landscapes and landscapes of people experiencing a coronavirus pandemic related trauma.

\section{CONCLUSIONS}

In order to investigate the psychological aspects of a person's lifechanging after the trauma, it is analyzed the experience of combatants after their returning from the war in the East of Ukraine. The 91 study participants were asked to write stories about their life based on the proposed posttraumatic narrative scheme.

In accordance with the research task, analysis topics of traumatic experience all fragments of the narratives were coded by themes: traumatic experience, life changes, negative effects, and a vision of the future. The traumatic war-situations are described in $41.9 \%$ of narratives, family problems in $24,7 \%$, grievous losses before the war - in $23.5 \%$, other traumas - in $9,9 \%$.

To explore changes in a person's life after experiencing trauma it was proposed 4 criteria: the comprehension level of a person's past; the assessment of the present; the vision of the future; the dominant life-value, around which a human being constructs his new life-trajectory.

The integral indicator of personal changeis life-landscape. The person's landscape transformations are defined as the territory of a person's life, which 
has special dynamics, structural and functional characteristics, significant semantic fullness.

The following types of landscapes have been identified: a) existential (it differs the unwillingness to rethink the traumatic past; to assess the present adequately; the inability to construct the future; the dominant for survival); b) communicative (it is distinguished by a good understanding of the past; adequate assessment of the present; detailed construction of the future; dominant of meaningful relationships); c) volunteering (it differs from communicative primarily by the dominant life-value - benefits for others); d) self-realization (it differs in the main value of self-development); e) pragmatic (it distinguished by the major value of career advancement). The most common landscapes are existential and communicative $(25.0 \%$ each); landscapes of volunteering and self-realization (17.3\% each) are in second place; on the third - pragmatic (13.6\%).

\section{SUMMARY}

The purpose of the work was to investigate the psychological aspects of a person's life-changing after the trauma. Combatants' transformations of life after returning from the war in the East of Ukraine was in the focus of this study. It was analyzed the 91 combatants' traumatic experience after their returning from the war-zone. Most of them were servicemen who are now students of the military higher educational establishment. In addition to them, there were some volunteers. The written narrative method was used because of its diagnostic and rehabilitative potential. The study participants wrote stories about their life based on the proposed post-traumatic narrative scheme. They were asked about stressful events, rethinking of traumatic experience, new perspectives. All fragments of the narratives were coded by themes connected to personal past, present, future and dominant life-value. The traumatic war-situations were described in $41.9 \%$ of narratives, family problems in $24,7 \%$, grievous losses before the war - in $23.5 \%$, other traumas - in $9,9 \%$.Personal life-landscape was defined as the integral indicator of transformations, the territory of a person's life, which had special dynamics, structural and functional characteristics, significant semantic fullness. It was studied the common types of person's life-landscapes after participation in the war. The following types of landscapes had been identified: a) existential (it differs the unwillingness to rethink the traumatic past; to assess the present adequately; the inability to construct the future; the dominant for survival); b) communicative (it is distinguished by a good understanding of the past; adequate assessment of the present; detailed construction of the future; dominant of meaningful relationships); c) volunteering (it differs from communicative primarily by the dominant life-value - benefits for others); 
d) self-realization (it differs in the main value of self-development); e) pragmatic (it distinguished by the major value of career advancement). The most common landscapes were existential and communicative $(25.0 \%$ each); landscapes of volunteering and self-realization (17.3\% each) were in second place; on the third - pragmatic (13.6\%). Prospects for further research is a comparative analysis of combatant's life-landscapes and landscapes of people experiencing a coronavirus pandemic related trauma.

\section{REFERENCES}

1. Arthur P. Trauma Online: Public Exposure of Personal Grief and Suffering. Traumatology. 2009. Vol. 15, № 4. P. 65-75.

2. Belrose C., Duffaud A.M., Dutheil F., Trichereau J., \&Trousselard M. Challenges Associated with the Civilian Reintegration of Soldiers with Chronic PTSD: A New Approach Integrating Psychological Resources and Values in Action Reappropriation. Frontiers in psychiatry. 2019. Vol.9, № 737. P. 50-60.

3. Bragin M. Can anyone here know who I am? Co-constructing meaningful narratives with combat veterans. Clinical Social Work Journal. 2010. Vol. 38, № 3. P. 316-326.

4. Bryant R.A., Nickerson A., Creamer M.C., O’Donnell M., Forbes D., Galatzer-Levy I.R., McFarlane A.C., \& Silove D.M. Trajectory of posttraumatic stress following traumatic injury: 6-year follow-up. The British journal of psychiatry. 2015. Vol. 206, № 5. P. 417-423.

5. Bruce A., Beuthin R., Shields L., Molzahn A., \& Schick-Makaroff K. Narrative Research Evolving: Evolving Through Narrative Research. International Journal of Qualitative Methods. 2016. Vol. 15, № 1. URL: https://doi.org/10.1177/1609406916659292

6. Caddick N.\& Smith B. Exercise is medicine for mental health in military veterans: A qualitative commentary. Qualitative Research in Sport, Exercise and Health. 2018. Vol. 10, № 4. P. 429-440. DOI: $10.1080 / 2159676$ X.2017.1333033

7. Carless D. Narrative Transformation Among Military Personnel on an Adventurous Training and Sport Course. Qualitative health research. 2014. Vol. 24. № 10. P. 1440-1450. URL: https://doi.org/ $10.1177 \% 2 F 1049732314548596$

8. Crone D.M., Sarkar M., Curran T., Baker C., Hill D., Loughren E., Dickson T., \&Parker A. Mental Health first aid for the UK Armed Forces. Health Promotion International. 2019. DOI: 10.1093/heapro/day112

9. Ermischer G. Mental landscape: Landscape as idea and concept. Landscape Researth. 2004. Vol. 29, № 4. P. 371-383. 
10. Hartley R.J. Signifying the Place of Unforgettable Memory: Atrocity and Trauma in a Post-Conflict Landscape. Anthropology Faculty Publications. University of Nebraska-Lincoln. 2014. URL: http:// digitalcommons.unl.edu/anthropologyfacpub/58

11. Hunt N. Landscapes of trauma. The psychology of battlefield. London, New York :Routlege, 2020. 220 p.

12. Mcmullin J. Integration or separation? The stigmatisation of excombatants after war. Review of International Studies. 2013. Vol. 39., № 2. P. 385-414. DOI:10.1017/ S0260210512000228

13. Muldoon O. \& Lowe R. Social Identity, Groups, and Post-Traumatic Stress Disorder. Political Psychology, 2012. Vol. 33. № 2. P. 259-273.

14. Jones L., \&Kafetsios K. Assessing adolescent mental health in waraffected societies: The significance of symptoms. Child Abuse \& Neglect. 2002. Vol. 26, № 10. P. 1059-1080. URL: https://doi.org/10.1016/S01452134(02)00381-2

15. Muldoon O. \& Lowe R. Social Identity, Groups, and Post-Traumatic Stress Disorder. Political Psychology, 2012. Vol. 33, № 2. P. 259-273.

16. Pietrzak R.H., Feder A., Singh R., Schechter C.B., Bromet E.J., Katz C.L. Southwick S. Trajectories of PTSD risk and resilience in World Trade Center responders: an 8-year prospective cohort study. Psychological Medicine. 2014. Vol. 44, № 1. P. 205-219.

17.Zięba M., Wiecheć K., Biegańska-Banaś J., \& MieleszczenkoKowszewicz W. Coexistence of Post-traumatic Growth and Post-traumatic Depreciation in the Aftermath of Trauma: Qualitative and Quantitative Narrative Analysis. Frontiers in Psychology. 2019. Vol. 10. DOI: 10.3389/fpsyg.2019.00687

18. Waysman M., Schwarzwald J. \& Solomon Z. Hardiness: An examination of its relationship with positive and negative long-term changes following trauma. J. Traum. Stress. 2005. Vol. 14. P. 531-548. doi:10.1023/A:1011112723704

19. Василькова В.В., Басов Н.В. Интеллектуальный ландшафт: концептуализация метафоры. Журнал сочиологии и социальной антропологии. 2011. № 14 (4). С. 22-40.

20. Міщенко О.В. Сакральний ландшафт: зміст і функції. Вісник наи. ун-ту ім. Т. Шевченка. Географія. 2018. № 1 (70). С. 83-88.

21. Сусська О.О. Інституціональністьvs проспериті. Про зміни медіаландшафту та методологічні лакуни соціології масових комунікацій. Соиіологія: теорія, методи, маркетинг. 2019. № 1. С. 56-72.

22. Титаренко Т.М. Психологічне здоров'я особистості: засоби самодопомоги в умовах тривалої травматизації: монографія. Кропивницький : Імекс-ЛТД. 2018. 160 с. 
23. Черняева Т. И. Ландшафты счастья: эмоциональные основания современного потребления. Известия Саратовского университета. Серия Философия. Психология. Педагогика. № 13. С. 90-94.

Information about the author: Tytarenko T. M., Doctor of Science in Psychology, Professor of the Institute for Political and Social Psychology, Full Member of National Academy of Education, 15, Andriivska str., Kyiv, 04070, Ukraine 